\title{
Uzun İhsan Efendi’nin Monolojik Sesi: Puslu Kitalar Atlası
}

\author{
Selçuk ATAY*
}

\section{Öz}

İhsan Oktay Anar'ın ilk romanı olan Puslu Kitalar Atlası, postmodern anlatının teknikleriyle kaleme alınmış bir romandır. On yedinci yüzyıl İstanbul'unda yaşayan Uzun İhsan Efendi'yi merkeze alınarak kurgulanan eser fantastik ögelerle yüklü bir roman olarak karşımıza çıkar. Anar'ın romanlarında genel karakteristik bir özellik olan bu öğeler sanatkârın ilk romanından son romanına kadar belirgin bir yapısal unsur olarak karşımızda durmaktadır.

Anar'ın romanları üzerine yapılan pek çok çalışmanın, bahsedilen fantastik ögelerin tespiti, postmodern kurgu unsurlarının tespiti gibi genel geçer betimleme çalışmaları etrafında toplanığı görülmektedir. Ancak diğer tarafta sanatkârın romanlarındaki dili kullanış biçimi veya romanının yapısal özelliklerinin oluşumu üzerine çok az şey söylenmiştir. Özellikle İhsan Oktay Anar'ın dili için karakteristik bir özellik olarak gösterilebilecek olan dil kullanımı ve bu dilin monolojik yapısı üzerinde durulmamıștır. Oysa sanatkârın romanını oluşturan en mühim taraf onun dili kullanışı ve bu yapısal özellikle kurgulanan tahkiye hususiyetidir.

Bu makalede İhsan Oktay Anar'ın Puslu Kitalar Atlası adlı romanı Mihail Bahtin'in monolojik söylemi etrafında tahlil edilecek ve monolojik söylemin ortaya çıkardığı yapı incelenecektir.

Anahtar Kelimeler: İhsan Oktay Anar, Puslu Kıtalar Atlası, Bahtin, monolojik söylem.

\footnotetext{
* Dr., Millî Eğitim Bakanlığı. Türkiye.

Elmek: atayselcuk@yahoo.com

https://orcid.org/0000-0001-5328-2257
} 


\title{
Monological Voice Of Uzun İhsan Efendi: Puslu Kıtalar Atlası
}

\begin{abstract}
Puslu Kitalar Atlast, the first novel of İhsan Oktay Anar, is a novel in which the author used the techniques of postmodern narrative. The work, which centers around the character of Uzun İhsan Efendi, who lived in Istanbul in the seventeenth century, is seen to contain fantastic elements. These elements, which are considered to be a general characteristic of Anar's novels, stand before us as a distinctive structural element in all his novels.

Many studies on Anar's novels are seen to have gathered around the general description of depictions such as the identification of the fantastic elements and the determination of the elements of postmodern fiction. But on the other hand, little has been said about the way the author uses the language in his novels or the formation of the structural features of his novels.

In this paper, İhsan Oktay Anar's novel Puslu Kitalar Atlası will be analyzed based on the monological discourse of Mikhail Bakhtin and the structure revealed by the monological discourse will be examined.
\end{abstract}

Keywords: İhsan Oktay Anar, Puslu Kitalar Atlası, Bakhtin, monological discourse. 


\section{Extended Summary}

İhsan Oktay Anar's Puslu Kitalar Atlasl, written in the form of a postmodern narrative, emerges as a novel progressing with the monological discourse of Uzun İhsan Efendi and loaded with fantastic elements. However, it calls the novel only "fantastic novel" or "postmodern novel" and the limitations put together with this naming hinder the complete evaluation of the novel. Because Puslu Kitalar Atlası is not only a novel that can be read through techniques. In this context, the method of the study is based on Bakhtin's concept of "monological novel".

As Bakhtin states, the monological novel has several indications. Whether the characters have their own self-consciousness has can be mentioned as the most obvious of these indicators. Throughout the article, it has been shown that İhsan Oktay Anar, rather than choosing Uzun İhsan Efendi as a narrator, has almost placed himself in the novel and in this way has attached the consciousness of all heroes to him. Consequently, the dialogues in the novel appeared in ideological and sometimes pedagogical nature along with finalizing judgments.

As another aspect of monological discourse, it is seen in the novel that a world composed of homogeneous materials is presented to the reader. Case rings of each protagonist, another culture, another past, have been able to stand together with the homogeneity of the material. The most distinctive feature of homogeneity is that the heroes are connected to each other by pragmatic ties.

The pedagogical situation that emerges in the personality of Uzun İhsan Efendi can be combined around the concepts of "self-knowledge" and "knowing the world". Every event that Bünyamin lives and will experience is considered as a means to reveal these two concepts. In this fictional text, which is only the opinion of Uzun İhsan Efendi, the right or wrongness of nothing and no event is discussed. This situation, which emerged as a necessity of monological discourse, reveals the objectified and finalized discourse of the work.

On the other hand, Bahtin shows an important aspect of monological discourse that differs from a dialogic discourse by stating that a situation is 
either accepted or rejected. In the novel of Anar, the idea of eternity pursued by the Great Master or the failure of other heroes at some point in their lives is an example of this denial. Indeed, it is emphasized that the existing world is recognized and recognizes one's own self in this context and makes the journey meaningful. The affirmation of this emphasis is achieved by negating others. Throughout the novel, talented characters in many ways fail and die due to the negated thinking structure, and Bünyamin, who does not have any apparent talent, will proceed on the path of self-realization with the positive image that emerges among these negativities. This situation can also be considered as an indication that a consciousness other than the one presented by Uzun İhsan Efendi could not be able to be placed in the novel.

Monological discourse, which mostly focuses on characters who are one of the basic elements of a literary text but does not neglect other elements of structure, takes the naturalness of human states to its center. This naturalness that emerges in a dialogical novel will be broken in a monological novel. Therefore, the dialogues will become artificial and will deny the fact that there is a novelist himself. Uzun İhsan Efendi, the ultimate authority, is forced to place the concept of "error" in the novel. Bünyamin is the only hero in the novel that is not stated to have made a "mistake". All heroes placed in the novel evolved into a very different situation by making mistakes, although they were quite proficient in their profession. However, Bünyamin does not make a mistake and becomes an object proving the discourse of the final authority.

When this part of the study is mentioned, it becomes necessary to mention Jean Baudrillard's concept of simulation. Because no character in the novel has its own self-consciousness. The characters simplify the reality of Bünyamin in the novel by simulating a real situation. This is another of the artificial elements of the novel emerges as.

As a result, the characters' division of the author's consciousness and providing a complementary structure within a narrative has created a situation that implies that they live as they should, not what they live as they believe. The original side of our study emerges at this point. Because so far, the Puslu Kitalar Atlası has been analyzed by placing certain techniques in the center, and 
studies have been concluded by showing that these techniques have been used in the novel. On the other hand, our study looks at the Puslu Kitalar Atlas from a structural perspective by focusing on the concepts of dialogue and consciousness and focuses on the analysis of the discourse of the novel. 



\section{Arayışla Bulunan Anlam yahut Anlamı Bulmak İçin Çıkılan Yolculuk}

İnsanoğlunun yaptığı yolculuklardan en çetrefil olanı şüphesiz kendi iç benliğinde yaptığı yolculuktur. Açık ve amacını tespit etmiş bir bilincin iradesiyle yapılabilecek olan bu yolculuğun merkezinde ise "anlam" bulunur. İnsanın kendisini ve kendisi dışındaki her şeyi yine kendi penceresinden anlamlandırması anlamına gelen bu süreç, öte yandan yolculuğun sonundaki kendiliğin aşılmış bir kendilik olmasını zorunlu kılar. Mantıksal önermenin sınırları içerisinde kabul edilebilen bu cümleyi pratik hayatın içerisinde ise "yaşamak" sözcüğünün anlam alanında değerlendirmek mümkündür.

İşaret etmeye çalıştığımız şekliyle yaşam, kendisine bir "anlam istemi”ni zorunlu kılacaktır. Victor Frankl'ın "logo-terapi” şeklinde ifade ettiği ve "geçici olan"dan "sonsuz olana" değin uzanan yolculuğu kapsayan bu zorunlu süreç (2007: 35) yine Frankl'a göre insanın temel ve "gerçek" bir ihtiyacı olan anlam istemi olarak bu yolculuğun merkezine oturur. Freud'un aksine yaşamın anlam alanını merak eden insanın "insanlığını kanıtladığına" inandığını söyleyen Frankl, öte yandan bu anlamlandırma arayışının, kimliğini bulmak yolundaki insanın kendini aşmaya götüren bir sonuç olarak da karşımıza çıkacağını ifade eder (Frankl, 2007: 32).

İnsan tekinin dünyada “var-ol” uşunu bu çabada ve dahası Ortega Gasset’ten hareketle "merak" duygusunda gören İbrahim Tüzer, İhsan Oktay Anar'ın da Puslu Kıtalar Atlası'nın merkezine bu merak unsurunu yerleştirmiş olduğunu söylemektedir. Tüzer'e göre romanda merakın kullanılışı, bir “giz”i romanın sonuna değin sürdürerek okumayı akıcı hâle getirmek değil; okuyucunun "zihinsel konforunu boz"maktır (2016: 25). Burada bozulan konfor ibaresinden, anlamlandırma ile iç dünyada yapılan yolculuğun oldukça girift oluşunun kastedildiği açıktır.

Postmodern anlatının imkânlarını kullanarak yazılan Puslu Kıtalar Atla$s l$, yukarıda işaret etmeye çalıştı̆̆ımız bireyin anlam arayışı çerçevesinde okunduğunda ve romanın art alanındaki anlam bu açıdan ortaya çıkarıldığında edebî 
eserin ontolojik yapısı gereği çoğalan anlam ve değer imkânları kendisini gösterecektir. Dolayısıyla romana yalnızca "fantastik" ögelerle yüklü bir roman olarak bakmak ve onu bu ögelerin 1şığında açıklamaya çalışmak veya vaka zamanını görece öne alarak "tarihsel" roman nitelemesinde bulunmak romanın anlam değerini kısırlaştırmaktan öte bir netice taşımayacaktır. ${ }^{1}$

İç içe geçmiş vaka halkalarının büyük bir bütünde birleştiği Puslu Kıtalar Atlası'nda İhsan Oktay Anar'ın rolünü anlamlandırmak da yine yukarıda izaha çalıştığımız yolculuğun bir parçası olarak görmek mümkündür. Zira eser daha başlığından itibaren "Puslu Kita" söz grubuyla bahsettiğimiz yolculuğa, "Atlas" sözcüğü ile anlamlandırmaya ve bu anlamlandırmanın monolojik bir ses tarafından yapıldı̆̆ına dair bir vurguyla başlar.

Romanda Uzun İhsan Efendi ile birlikte görünür hâle gelen yazar-anlatıc1, romanda sembolik olarak oluşturduğu atlas ile yolculuğun aşamalarını okuyucuya sunmaktadır. Uzun İhsan Efendi tarafından hazırlanan ve Bünyamin tarafından pratikte karşılığını bulan atlas ile birlikte Uzun İhsan Efendi’nin tüm kahramanlar üzerindeki etkisi, şüphesiz, romanın tek sesli bir anlatı hâline gelmesine neden olmakta, romandaki tüm kahramanlar Uzun İhsan Efendi'nin şahsında toplandıktan sonra İhsan Oktay Anar'a bağlanmaktadır. Anar, Hegelci anlamda çelişkililiği toplumun nesnel dünyasında değil felsefi söylemde bulmuştur. Metnin gerisinde duran yazarın, toplumun bir ferdi olarak sözünü metinde yücelten bu algılayış biçimi onun yapıtının monolojik bir söylem etrafında şekillenmesini zaruri kılan romantik bir duyuş tarzıdır.

\section{Tek Bilinç, Birden Fazla Hayat}

Bahtin, kahramanların öz-bilinçlerine yapılacak olan yorumların sosyolojik açıdan ele alınması gerektiğini vurgular. Ancak bunun için kahramanların hakikaten kendilerine ait bir öz-bilinçle romandaki yerlerini almış olmaları gerek-

\footnotetext{
1 Kanaatimizce bu sınıflandırma denemelerinden her ikisi de bir tarafıyla eksik kalmaktadır. Todorov, bir edebî eserin düş veya gerçek kavramlarına verileceği cevapla tekinsizliğe veya olağanüstülüğe ulaşılacağını söyler. Ona göre fantastik bu ikisi arasında kalan alanı göstermektedir (2012: 31). Roman boyunca Uzun İhsan Efendi'nin düşlemesinin sürdüğünü, tüm romanın bu düşlemelerin etrafinda şekillendiğini defalarca tekrar edilmekte, üstelik bu söylemi bozan herhangi bir duruma rastlanmamaktadır. Dolayısıyla bu haliyle eser Todorov'un "tekinsiz" diye adlandırdığı türe dâhil edilebilir. Öte yandan fantastik roman alegorik okumaya kapalı bir yapı sergiler. Ancak Puslu Kıtalar Atlası için böyle bir kapalılıktan bahsedilemeyeceği, simgelerin hangi kavram etrafında oluşturulduğu metnin anlatıcısı tarafından pek çok kez okuyucuya sunulmuştur.
} 
mektedir. "Öz-bilinç, kahraman imgesinin kuruluşundaki sanatsal boyut olarak kendi başına sanatsal bir dünyanın monolojik bütünlüğünü yıkmaya yeterlidir; ama ancak kahramanın öz-bilinç olarak ifade edilmekle kalmayıp gerçekten bu şekilde temsil edilmesi, yani yazarla kaynaşmaması, yazarın sesi için bir dublör işlevi görmemesi koşuluyla; dolayısıyla, ancak kahraman öz-bilincinin vurgularının gerçekten nesnelleştirilmiş olması ve yapıtın kendisinin kahraman ile yazar arasına bir mesafe koyması koşuluyla yapabilir bunu." (2004: 102-103) O halde Anar'ın yapıtı monolojik bütünlüğü yıkacak bir imgeden mahrumdur.

Romanı diğer türler arasında ayrıcalıklı bir yere oturtan Bahtin'e göre mühim olan kahramanların dış görünüşleri değil, dünyanın kahramana nasıl göründüğüdür (2014: 56). Dolayısıyla söz konusu ettiğimiz dünyayı ve kendini anlamlandırış, kahraman imgesinin kuruluşunda önemli bir yapı arz etmektedir. Böyle bir bakış açısı öz-bilince sahip, anlatıcının tekil sesine değil kendi sesini romana yerleştirmeyi başarmış kahramanları ortaya çıaracaktır.

Görüldüğ̈̈ üzere dilbilimin, sözcelemeyi "pasif” bir yap1 olarak görmesine karşı çıkan Bahtin, ortaya koyduğu "çokseslilik" kavramı ile romanda "aktif bir anlama" işaret etmektedir (2014: 56-57). Daha çok, merkeze koyduğu Dostoyevski'den yaptı̆̆ Bahtin'e göre romanlar monolojik ve diyalojik söylemlerden oluşur. En genel ifadesiyle kahramanların söylemlerinde kendisini gösteren bu iki yapı, onların kendi bilinçlerine sahip birer kahraman olarak romanda yer bulup bulmamaları ile ilgilidir. Buna göre bir romancı için asıl olan her biri kendi bilincine sahip kahramanların oluşturduğu çok sesli bir romanı kurgulayabilmektir. Elbette bu durumda yazarın romandaki konumunun da tespit edilmesi gerekmektedir. Bir yaratıcı olarak yazarın bilinci romanın her yerinde mevcut olabilir. Ancak monolojik romandan farklı olarak çoksesli bir romanda "yazarın bilinci başkalarının bilinçlerini nesnelere dönüştürmez ve onlara gıyabi, nihaileştirici tanımlar yapıştırmaz.” (2004: 122)

Romanda kullanılan monolojik söylem İhsan Oktay Anar'a türdeş malzemelerden kurulu bir dünya sunmuştur. Sıradan insanların sıradan olmayan yaşam öyküleri bu hâliyle bütünlüklü olarak bir arada durabilmektedir. Farklı yaşamöyküleriyle Konstantiniye'de birleşen bu insanlar, bahsedilen monolojik 
söylemle, daha doğrusu yazarın tekil bilincinin farklı görüntüleri olmalarıyla bir ahenk oluşturacak şekilde romanın içindeki yerlerini alırlar.

Anar'ın romanlarındaki kişiler birbirlerine pragmatik bağlarla bağlanmışlardır. Dolayısıyla bu durum onların birer nesne olarak görülmelerini sağlamaktadır. Yazarın zihnindeki bütünlüklü dünyayı bağlayıp birleştiren bu karakterler tek bir bilincin farklı görüntülerini sunarlar. Buradaki monolojik durum görece bağımsız görünen kahramanların yazarın bilincindeki öznel yapıya uyum göstermekte oluşlarıyla ortaya çıkar. Kahramanların her biri anlamsal sınırları içinde bir bilince sahiptir. Bu ise yazara ait nihaileştirilmiş bir önyargının romanda varlığını gerekli kılar. Yazar romanın sonundaki mektupta bu nihai yargıyı dile getirmektedir:

"Sevgili oğlum,

Bir zamanlar yaşadığım evin, geceyarısı eve dönerken taşıdığım o fenerin, duvardaki Acem halısının ve aslında gerçek bir kent olan Galata'da gördüğüm her şeyin sadece ve sadece benim zihnimdeki düşünceler olduğu fikri kafama saplandığında muhakeme gücümün zayıfladığına hükmetmiştim. Ama şimdi görüyorum ki, asıl bunu düşündügü̈mde yanılmışım. Çünkü onlar gerçekten benim düşlerimdiler.

( ...)

Zihnimde bir düş olan sevgili oğlum, işte böyle zavallı babanın yaşayamadıklarını yaşadın ve dokunamadıklarına dokundun. Bir babanın kendi oğlundan bekleyeceği şekilde kahraman değildin. Son derece silik ve mütevaziydin. Bununla birlikte, arada bir senin kulağına, karakterinle bağdaşmayacak sözler fisıldamadan edemedim. Çünkü düşler görmektense, boşluğun kendisine tapan insanlar karşısında küçük düşmeni istemedim. Sonunda, senin için düşlediğim macerayı yaşadın ve böylece senin için yazdığım atlası okumuş oldun. Artık benden öğreneceğin nihai şeyi öğrenmiş oluyorsun.” (236-237)

Görüleceği üzere Uzun İhsan Efendi, bir baba olarak oğlu Bünyamin'in yaşayacağı her şeyi kendi düşlemiş ve onun sözlerine varıncaya kadar hemen her şeye müdahale etmiştir. Dolayısıyla roman boyunca ortaya çıkan her durum ve karakter Uzun İhsan Efendi'nin bilincinin yansıması olarak ortaya çıkmıştır.

Puslu Kıtlar Atlası'nın olay örgüsü birbirinden bağımsız gibi görünen karakterlerin romana dâhil olması ve bu karakterlerin yollarının kesişmesi ile zincirleme bir halkalar yığını hâlinde okuyucuya sunulmaktadır. Çok iyi bir kılık değiş- 
tirme ustası Hınzıryedi'nin Acem diyarından çıkıp dilenciler locasının kethüdası hâline gelişi, bütün romandan neredeyse bağımsız olarak Alibaz'ın başından geçenler, Ebrehe ve Büyük Efendi'nin gayeleri vb. romanın olay örgüsü içerisinde muhakkak kesişir. Ancak buradaki kahramanların tamamı birbirlerinin görüş alanının dışında durmaktadırlar. Ne Büyük Efendi, ne Bünyamin, ne Vardapet ve ne de bir başkasının bilincinin bu noktada bir birlikteliği görülmemektedir. Vaka zincirindeki görece birliktelikten ziyade bilinçteki bu ayrılık görüntüsel olarak bir arada oluşu, fakat bilinç olarak ayrılığı göstermektedir. Dolayısıyla kendi içlerinde kapalı olan bu kahramanlar birbirlerine de kapalıdırlar. Bu kapalı oluşu çözen ise karşımıza düşleriyle çıkan Uzun İhsan Efendi'dir. Yazar anlatıcının romandaki izdüşümü olan Uzun İhsan Efendi, yazarın görüş açısındaki tüm imkânlara sahip olarak anlatısını sürdürür. $\mathrm{Bu}$ ise anlatının nihaileştirilmiş bir monolojik işlevinin olduğunu göstermektedir: "Düşündüğüm için ben var değilim, sizler varsınız. Sizler benim zihnimdeki düşüncelerden ibaretsiniz.” (s. 190)

Bahtin'e göre "mantıksal bağlantı, bütünlüklü bir kişinin canlı sesinde cisimleşmiş olan bu somut bilinç aracılığıyla, temsil edilen bir olayın bütünlüğünün parçası hâline gelir" (2004: 53). Puslu Kıtalar Atlası'nda Uzun İhsan Efendi'nin bilinci, Anar'ın müdahaleleriyle somutlaşır ve kahramanların hepsi üzerinde cisimleşir. Ortaya çıan "fikir-duygu", romanın monolojik söylemini yadsınamaz bir biçimde ortaya koyar. Burada beliren durum metnin merkezine konulan "dünyayı görme"ye dair somut verileri okuyucuya sunar.

Yazar anlatıcının dünyayı, dolayısıyla kendini tanımaya dair söylemi metnin yegâne ideolojik söylemi olarak karşımızda durmaktadır. Bahtin, "monolojik bir sanatsal dünya[nın] bir başkasının düşüncesini, bir başkasının fikrini temsil nesnesi olarak kabul etmeye"ceğini savunarak bu tür düşüncelerin temsil edilemeyeceğini; “ancak olumlana”bileceğini söyler (2004: 133). Anar'ın romanında baskın olan monolojik söylem tıpkı Bahtin'in ifade ettiği biçimiyle üzerinde konuşulan, doğru ve yanlışı̆̆ğı tartışılan, bir özbilinç sahibi kahramanın süzgecinden geçen söylem olarak değil; olması gereken bir söylem olarak okuyucuya sunulur. Şüphesiz bu durum yapıtın nesnelleşmiş ifadesini ve nihaileşmiş söylemini ortaya koyan bir durumdur.

Diğer taraftan Bahtin, monolojik söylemin, bir durumu "ya kabullen"diğini ya da "yadsındığını" (2004: 134) ifade ederek diyalojik söylemden ayrılan önemli 
bir yanını göstermektedir. Anar'ın romanında Büyük Efendi'nin peşine düştüğü sonsuzluk ideali veya diğer kahramanların hayatlarının bir noktasında başarısızlığa uğramaları hep bu yadsınmanın birer örneğidir. Zira asıl olan, var olan dünyanın tanınarak insanın kendi benliğini bu bağlamda tanıması ve yapacağı yolculuğu anlamlı k1lması vurgusudur. Bu vurgunun olumlanması diğerlerinin olumsuzlanmasıyla sağlanmaktadır. Roman boyunca pek çok anlamda yetenekli olan karakterler olumsuzlanan düşünce yapısı gereği başarısızlığa uğrayıp ölürlerken herhangi bir belirgin yeteneği olmayan Bünyamin bu olumsuzlamaların arasında ortaya çıkan olumlu görüntü ile kendini gerçekleştirme yolunda ilerleyecektir. Bu durum aynı zamanda Uzun İhsan Efendi'nin şahsında ortaya konulan bilinçten başka bir bilincin romana yerleştirilmeye muktedir olunamayacağının da göstergesi olarak değerlendirilebilir.

Yukarıda bahsedilen ifadeleri romanda hiçbir kahramanın zihinsel bir değişim ve dönüşüm geçirmemesi ile desteklemek mümkündür. Anar, Uzun İhsan Efendi'nin kişiliğini belirledikten sonra nesneleştirmiş ve psişik olarak bu nesneyi diğer karakterler arasında paylaştırmıştır. Onun tahayyülü ve romandaki tüm tasvirleri bu psişik bölümlenmenin anlatılmasından ibarettir. Vaka örgüsüne bağlı birtakım fiziki değişimler gerçekleşmiş olsa da zihnî yapıda bir farklılık hiçbir kahramanda görülmemektedir. Bünyamin'de oluşması beklenen dönüşüm ise kahramanın zihnine bir bütün hâlinde verilir. Dolayısıyla roman boyunca hiç değişmeden kalan anlamsal bir yapı ortaya çıkarılmış olur. Her şeyi bildiğini ve herkesi yönlendirdiğini savunan Uzun İhsan Efendi, bu hâliyle hiçbir düşüncenin evrimine izin vermemektedir.

Puslu Kıtalar Atlası'nda her karakter yazar anlatıcı tarafından nihaileştirilmiş bir dünyanın figüranları konumundadır. Bu bağlamda karakterlerin yaşadıkları deneyimler içsel bir yönlendirmenin ortaya çıkarmadı̆̆ı, yazar anlatıcının kendileri için biçtiği rolün birer parçaları olmaktan ibarettir. Ortaya koyduklar1 mücadeleler de yine aynı şekilde ortak bilincin görüntüleri olmaktan öteye geçmemektedir. Burada sosyolojik bağlamda kullanılan 'bilinç' sözcüğü içsel bir ifade vasıtası olarak algılanmaya da müsaittir. Her kahramanın diyaloğu ya bir hakikati dile getirmeye ya da yazar anlatıcının fikirlerini aktarmaya dayalı, sonuna kadar bir forma sokulmuş görüntüler sunar. Bu anlamıyla hayatın normal 
seyrinde karşımıza çıkmayacak yapay diyaloglar olarak beliren söylem ideolojik bir yapıya bürünmüş olur.

Mihail Bahtin, Dostoyevski'nin romanlarını incelediği çalışmasında “diyaloji" ve "monoloji” kavramları üzerinde dururken bunun Dostoyevski'nin en orijinal taraflarından biri olduğunu söyler. Zira ona göre "romanlarda yeni olan şey, diyalogda tezahür eder.” (2004: 319) Diyalogların bir bilince sahip olan kahramanlar tarafından kurulması romanın önemli başarılarından biri olacaktır. Bu bağlamda bakıldığında Puslu Kıtalar Atlası'nın böyle bir imkândan mahrum olduğu görülecektir.

Bahtin diyalojik söylemde sözcenin bir iletişim halkası olduğunu söyleyerek önemli bir noktaya daha dikkat çeker: Ona göre romanda "kendisinden önce gelen, onu içeriden ve dışardan belirleyen, onda doğrudan cevabi tepkilere ve diyalojik yankılara yol açan halkalardan asla koparılmamalıdır” (2016: 101). Eğer bu halkalar koparılırsa bir sözcenin hem yazanı/söyleyeni hem de okuyan1/ dinleyeni olduğu gerçeği yadsınmış olur. Bahtin'in, sözcenin "hitaplılığı" dediği durum muhatap ile birlikte anlamlanır. Anar'ın romanındaki konuşmalarda koparılan bu halkalar anlatıcı tarafindan doldurulur. Konuşucu sözcelerini bitirdikten sonra monolojik olan söylem yeni bir duruma yol açmayacağ 1 , bir karşıllık oluşturmayacağı için diyalog aniden kesilir ve söylenecekler anlatıcı tarafından tamamlanır:

“-'Babacığım!' dedi, 'Beni ne görüyor, ne duyuyorsun, ama ben, gerçekten oğlun Bünyamin'im'.

Zavallı adam başını kaldırıp oğlunun elini tuttuktan sonra,

- 'Kör ve sağır olmama rağmen seni hem görüyor, hem de duyuyorum oğlum' dedi, 'Aslında seni görüp duymaktan da öte, hem seni, hem de içinde yaşadığın dünyayı düşünüyorum'.

$\mathrm{Bu}$ sözleri işiten Bünyamin kendini iyice koyverip hüngür hüngür ağlamaya başladı. Başına gelen bunca şeye dayanamayan babasının delirdiğine hükmetmişti. Fakat adam mezarın başından kalkıp hüzünlü ve derin bir sesle oğluna,

- 'Sizler, hepiniz, içinde yaşadığınız dünya, Kostantiniye, her şey, sadece ve sadece benim düşüncemde varsınız' dedi. 'Rendekar yanılıyor: Düşünüyorum, ama sadece ben var değilim. Düşündüğüm için asıl sizler varsınız; sizler ve içinde yaşadığınız dünya.' 
Hüngür hüngür ağlayan delikanlı, koluna girdiği babasıyla birlikte Galata’ya doğru ilerlerken Uzun İhsan Efendi hâlâ,

- 'Her şey ben ve benim düşüncelerimden ibaret olsa da bu dünyada yaşamak zevkli bir şey' diyordu, 'Sen! Oğlum! Sen benim zihnimde bir düş, bir düşüncesin. Bana şu anda dokunuyorsun. Ama ben sana dokunamıyorum. Çünkü düşlere dokunmak mümkün olabilir mi?’.

Bundan sonra olanlar, ağlamaktan gözleri kan çanağına dönen Bünyamin'e bir kâbus gibi göründü. (...) Uzun İhsan Efendi sanki düşüncelerini okumuş gibi oğluna, ikide bir arkasına bakmamasını, çünkü zihniyle olaylara yön verebildiği için emniyette olduklarını söylüyordu.” (s. 126-127)

Romanın her yerinde kendisi veya düşünceleri olan Uzun İhsan Efendi, "yön ver"diği romanı, bu haliyle tek başına yürütür. Yukarıdaki alıntıda da görüldüğü üzere tüm roman kesilen veya önceden hazırlanmış diyaloglardan oluşmaktadır. Bu durumda okuyucu romanın akışını değil, Uzun İhsan Efendi’nin ne "düşle"yeceğini veya ne söyleyeceğini beklemeye başlayacaktır. Bahtin'in "sözcükten bir şeyler beklemeyi bırakırsak, söyleyebileceği her şeyi önceden bilirsek, o sözcük diyalogdan çıkıp şeyleşir” (2016: 127) şeklinde dikkat çektiği bu durum, monolojik söylemin ve monolojik bir ilişkinin varlığında mümkün olmaktadir.

\section{Nihai Otoritenin Arzusu: Mutlak Doğru ve Hatasız Oluş}

Puslu Kitalar Atlası'nda monolojik söylemin önemli bir göstergesi olarak tek bir bilincin olduğu yukarıda ifadeye çalışırken öte yandan bu bilincin olumladığı tek kahraman olan Bünyamin dışındakilerin "hata" yaptığ 1 ifade edilmiştir. Uzun İhsan Efendi'nin düşlerinde kimliklerini bulan tüm kahramanlar, kendilerinin tanıtıldığı bölüm başlarında mesleklerinin en iyisi iken yaptıkları hatalarla Konstantiniye'ye gelmişlerdir. Öte yandan buradaki maceraları da daima olumsuzlanarak bitirilmektedir. Bu durumun yegâne sebebi olarak yazar anlatıcının idealist yaklaşımı gösterilebilir. Bahtin’in belirttiği üzere "idealizm yalnızca tek bir bilişsel bireyselleşme ilkesi tanır: hata" (2004: 135) cümlesi, romanda Bünyamin hariç her kahramanın muhakkak bir hatada bulunmasını açıklar niteliktedir.

Hazırladığı özel ilaçlarla uykuya geçmeyi ve daha fazla süre uykuda kalmayı amaçlayan Uzun İhsan Efendi, böylelikle olanaksızı olanaklı kılmak için 
yeterli motifi de sağlamış olur. Sıradan hayatın içerisinde imkânsız olan her husus bu sayede olanaklı hâle gelir ve sıradanlaşır. Kimi zaman tesadüflerle örülmüş olan bu hatalar o kahramanın yadsınan tarafını bize göstermektedir. Kahramanlar inandıkları gibi yaşama girişimlerinde monolojik söylemin bireyselleştirici etkisinden kurtulamazlar ve bu yaşam tarzı romanda hata ile birleştirilerek yadsınmış olur. Özgürlüğü, "insanoğlunun değiştirme iradesi” (Man, 2008:159) şeklinde tanımlayan önermenin doğruluğu kabul edilirse o hâlde romanda Bünyamin dâhil hiç kimsenin böyle bir hakkının olmadığı anlaşılacaktır. Hiçbir kahramanın özbilincinin olmadığg romanda böylesine bir özgürlüğün olmayışı kendilerini tamamlayan iki unsur olarak alımlanabilir. Bu ise kendisini öncelikle diyalogların yapaylığında göstermektedir:

““- Gör işte delikanlı’ dedi, ‘Dünyada neler oluyor. Hınzıryedi’yi küçümsemekle nasıl da büyük bir hata yaptılar. Oysa ben aylardır onları izliyordum. Sabrettim, bekledim ve faka bastırdım. Şu, senin Büyük Efendi'ne de bana yaptıklarını ödeteceğim. Bu arada sen de kurtulduğunu sanma. Çünkü artık senin de onlardan olduğunu düşünüyorum. Eğer onlardan yana olmasaydın, şu geçen uzun sürede, sana onca yardımı dokunan Hınzıryedi'yi arayıp bir hatrını sorardın. İşret âlemlerine katıldığından falan haberin olmadığını sanmak. Ama dua et ki, ben temkinli, düşünceli, anlayışlı bir insanım. Bu yüzden seni, hemen şuracıkta öldürecek değilim. Ama diğer arkadaşlarının taş çatlasa yarım saat ömürleri kaldı.” (s. 214-215)

"Yolun sonu göründü sevgili Bünyamin. Benimle birlikte büyük bir bilgi kaynağ1 da yok olacak diye çok üzülüyorum. Kastettiğim şey, teşkilatın yıllardır biriktirdiği bilgiler. Uzak ülkelerdeki casuslar merkezden haber alamayacakları için artık dağılıp gidecekler. (s. 215)"

Teşkilatın gizli merkezinin yağmalandığı, herkesin öldürüldüğü bir sahneden alıntılanan paragraflarda da görüldüğü üzere diyaloglarda bu karmaşanın izlerine rastlamak mümkün değildir. Bununla birlikte anlatıcı, bu karmaşanın arasında okuyucunun anlaması ve vaka örgüsünü mantıklı bir şekilde yorumlamas1 için elden geldiğince açıklamalarda bulunmakta ve konuşmanın doğal seyrini bozmaktadır:

"Böylece güçsüzlüğün ve silikliğin ne olduğunu öğrenme firsatı buldum. Aynı zamanda gücün ve her türlü iktidar tutkusunun da ne kadar büyük bir erdemsizlik olduğunu da bu sayede gördüm. Hayatta kalabilmek için bizler kadar 
çaba göstermiyordun. Yokedilmeye çoktan razıydın. Senin amacın varlığını sürdürmek değil sanki bambaşka bir şeydi. Sen bir şahittin. Evet, artık bundan eminim. Kesinlikle bir kahraman değildin. O küstahça sözlerini de sanki biri kulağına fisıldıyor ve benimle adeta alay ediyordu. Sanki benim, onların ve herkesin başına gelen bütün şeyler senin görmen, öğrenmen içindi.” (s. 216)

Hayatın sırrını keşfetmek adına Bünyamin'e attırılan her adımın çözümlendiği ve Bünyamin'in bunların farkına vardığı bu bölüm, yukarıdaki alıntıdan da anlaşılacağı üzere pedagojik bir yap1 arz eder. Bu ise Puslu Kıtalar Atlası'nın monolojik söyleminin bir başka yönünü oluşturmaktadır. Nihaileştirilmiş bir otorite ve onun bilinci tarafından bölümlenerek insanın iç yolculuğunun sembolik bir formda okuyucuya sunulduğunu söylediğimiz roman bu hâliyle diyaloglarındaki yapaylığı da farklı bir cepheden bize göstermiş olmaktadır. Bahtin, monolojik söylemin kendisini gösterdiği bu diyaloglar için şunları söylemektedir: "Felsefi monolojizm ortamında bilinçlerin sahici etkileşimi mümkün değildir, dolayısıyla sahici diyalog da mümkün değildir. (...) Hakikati bilen, hakikate sahip olan birisi, hakikatten bihaber veya yanılgilar içinde olan birisini bilgilendirir; yani bu bir öğretmenle öğrenci arasındaki etkileşimdir; demek ki olsa olsa pedagojik bir diyalog olabilir.” (2004: 135-136) Romana yerleştirilen her kahramanın hata yaparak bedelini ödemesi, öte yandan Bünyamin'in etrafında olup bitenleri sadece izlemesi ve bu sayede hakikate ulaşması bu yolla sağlanmıştır.

\section{Simülasyon ve İdeolojik Söylem}

Gizlemenin varlığa, simüle etmenin ise yokluğa gönderme yaptığını vurgulayan Jean Baudrillard (2014: 16) bu hâliyle "mış gibi yapma"nın simülasyondan farklı olduğunu belirtir. Zira simülasyon gerçek-sahte veya gerçek-düşsel arasındaki farkı ortadan kaldırmaya çalışmaktadır. Bu anlamda Puslu Kıtalar Atlası'nın kahramanlarına bakıldığında Uzun İhsan Efendi ve diğerleri arasında ciddi bir farkın olduğu görülecektir. Monolojik söylemin bir göstergesi olarak görebileceğimiz, geçmişleri tanıtılarak anlatıya dâhil olan her kahramanın ve öte yandan geçmişi tanıtılmayan tek isim olan Bünyamin'in görece farkı, simüle edilen söylemde birleşmektedir. Aslında bir kadın olan ama kimliğini saklayan Büyük 
Efendi, yüz değiştirmede mahir olan ve Kostantiniye'de yeni bir hayata başlayan Hınzıryedi, kiliseden kovularak lağımcılıkta nam salan Vardapet gibi tüm kahramanlar okuyucuya sunulan geçmişlerinden çok farklı bir hayat yaşamaya başlarlar. Öte yandan Bünyamin ise ilk planda yeni ve farklı bir hayata başlamamış olsa da savaşta kaybettiği yüzü ile diğer kahramanların bu durumunu bütünlemektedir. O hâlde Uzun İhsan Efendi yaptığı ilaçlarla gerçek-düşsel arasındaki farkı ortadan kaldırmaya çalışan bir simülark iken yarattığı tüm karakterler "yeniden canlandırma” (Baudrillard 2014: 20) motifi üzerine kurulu ütopik bir dünyanın figürleridir. Bünyamin ise bu figürlere hem yüzünü kaybedip yeni bir hayat yaşamaya başlaması hem de toprağa gömülüp tekrar çıkması ile dâhil olmuştur.

Oldukça girift hâlde sunulan ve yoğun bir şekilde okuyucuya verilen olay örgüsünün hiçbir aşamasında kahramanların "acı" çekmemeleri yaşadıkları süblimasyonun bir başka boyutunu oluşturur. Aşağıda belirtileceği üzere bir yönüyle Uzun İhsan Efendi’ye bağlı olan tüm kahramanlar, bir bütüne bağlı oluşlarıyla kendilik bilincini süblime etmekte ve acı çekmemektedir.

Monolojik söylemin bir başka yönü kendisini ideolojik söylemde göstermesi olduğu belirtilmişti. Bir bakımdan yukarıda ifadeye çalıştı̆̆ımız pedagojik diyalogla birleştirilebilecek bu söylem, diğer yandan da nihai otoritenin bilincinin görünür kılınmasındaki motiflerden biri olarak görülmelidir. Yazar anlatıcı yapay olan diyaloglarında belirli bir fikrin temsilciliğini yapmakta ve böylece daha ziyade Bünyamin'e doğru söylenen sözlerde kendisini göstermektedir. Bu yönüyle pedagojik bir hüviyet kazanan diyaloglar diğer taraftan ideolojik bir karaktere bürünmüş olmaktadır.

Bir Tanpınar Yorumu: Haz ve Günah adlı çalışmasında Huzur romanının monolojik bir söylemden ibaret olduğunu ifade eden İbrahim Şahin, romandaki bu durumun "ritim" unsuruyla kırıldığını belirtir (2012: 126). Ona göre Mümtaz ve Nuran arasında yapaylaşan ve satıhta kalan diyaloglar Mümtaz'ın iç diyaloglarında derinleşmekte ve değişmektedir. Bu durum romanın iç dinamiğini oluşturmaktadır. Ancak Anar'ın romanlarından Şahin'in belirttiği türden bir ritme de rastlamak mümkün değildir. Orada daha çok nihai otoritenin hayatı kavramaya, kişinin kendisini keşfetmesine dair söyleminin ispatlanması kaygısı kendisini göstermektedir. 
Romanda kahramanların farkındalığı bir başkasının farkındalığı ile (özellikle Uzun İhsan Efendi ile) iç içe geçmiş durumdadır. Bununla beraber kahramanların cümleleri de başkalarının cümleleriyle doludur. Burada öznel ve nesnel dilden bahsetmek ve bunun ideolojik dil ile olan ilişkisini belirlemek gerekmektedir. Çalışmasını öznel ve nesnel akıl olarak belirlediği iki kavram üzerinde temellendiren Max Horkheimer, öznel akıl için “esas olarak araçlarla ve amaçlarla ilgilidir; az çok baştan kabul edilmiş amaçlara ulaşmak için seçilen araçların yeterli olup olmadığı üzerinde durur" (2013: 55) der. Aklın bu durumu dilin otomatikleşmesine sebep olmakta ve düşüncelerin "kendi başlarına anlamlı olarak görülmelerini güçleştir"mektedir (Horkheimer, 2013: 68).

Yalnızca Uzun İhsan Efendi'nin amaçları doğrultusunda anlamlı kılınan ve çok geniş bir coğrafyadan Konstantiniye'ye toplanarak birleştirilen olay örgüsünün tek başına anlamlı birer parçadan ibaret olmaması dilin düşünceyi otomatikleştirmesinden kaynaklanmaktadır. Anar, Uzun İhsan Efendi'nin kişiliğini belirledikten sonra nesneleştirmiş ve psişik olarak bu nesneyi diğer karakterler arasında paylaştırmıştır. Onun tahayyülü ve romandaki tüm tasvirleri ise bu psişik bölümlenmenin anlatılmasından ibarettir. Buradaki bölümlenme Uzun İhsan Efendi’nin nesnel aklını ve onun teorik yapılanmasını pratiğe döktüğü Bünyamin'e dair düşlemeleri bahsettiğimiz üzere önceden kabul edilmiş amaçlara ulaşmayı merkeze almaktadır. Zira roman içerisindeki herkes Bünyamin'in iç yolculuğuna dair bir bölümü göstermekte, Uzun İhsan'ın kişiliğinin bir yönünü temsil etmektedir.

\section{Sonuç ya da Hiç Bitmeyen Yolculuk}

Türk insanının Tanzimat sonrası girdiği yeni medeniyet dairesi yaklaşık 150 yıldır pek çok evreden geçmiş, buna mukabil edebî mahsuller yaşanan sosyal ve kültürel hadiselerle birlikte başlangıcından oldukça farklı bir yere gelmiştir. 2000'li yıllardan itibaren ülkemizdeki edebiyat ortamında daha fazla görünür hâle gelen postmodern açılım İhsan Oktay Anar'ın Puslu Kıtalar Atlası başlıklı romanında da kendisini göstermektedir. Pastiş, kolaj, üstkurmaca ve hatta kimi zaman parodi ile birlikte yazılmış olan bu roman asıl ehemmiyetini ise insanın kendi iç dünyasında yaptığ 1 yolculuğu göstermesi ve bu yolculuk esnasında ortaya çıkan anlama dair hususiyetleri merkeze almasıyla kazanır. Romanın sonunda "atlasını" 
koynuna koyan Bünyamin'in "karanlığın” bizzat kendisi, "görülen” ve dahi “görülmeyen" düşlerin kaynağı hâline gelişi, atlasın koyununda kalışıyla birlikte hiç bitmeyecek bir yolculuğu imlemektedir.

Uzun İhsan Efendi'yi romandaki sesi olmaktan daha fazla bir yere konumlandıran Anar, böylelikle bir yazar olarak bilincini romana dâhil etmiş, ancak bununla beraber romanda monolojik bir yapının oluşmasına sebep olmuştur. $\mathrm{Bu}$ yapı olay örgüsünde meydana getirilen “giz”le birlikte sürükleyici bir şekle bürünse de kendilerine ait bir öz-bilinçleri olmayan, kendilerine ait bir göndergesi olmayan ben'liğin imleyicisi kahramanlar ve bu kahramanların doğal bir akış içerisine yerleşmeyen diyalogları metnin monolojik bir anlatıya dönüşmesine olanak vermiştir. Öte yandan olay örgüsüne katılan entrikaların haricinde romandaki bu monolojik yapının bütünlüğünü kırmasına imkân veren bir unsurun romanda olmadığı görülmektedir. Kendi bilinçleri olmayan kahramanların hem hayatları hem birbirleri ile olan ilişkileri gerçek bir oluştan ziyade simülasyona dayanan bir ilişki içine girmelerine sebep olmaktadır. Kahramanların, yazarın bilincinin bölümlenmiş ve bir anlatı içerisinde birbirini bütünleyen yapı arz etmeleri onların inandıkları gibi yaşadıklarını değil yaşamaları gerektiği gibi yaşamalarını imleyen bir durum ortaya çıkarmıştır. 


\section{Kaynakça}

Anar, İhsan Oktay (2015), Puslu Kıtalar Atlası. İstanbul: İletişim Yayınları.

Bahtin, Mihail M. (2004), Dostoyevski Poetikası'nın Sorunları, çev. Cem Soydemir, İstanbul: Metis Yayınları.

Bahtin, Mihail. M. (2014), Karnavaldan Romana, çev. Cem Soydemir, İstanbul: Ayrıntı Yayınları.

Bahtin, Mihail M. (2016), Söylem Türleri ve Başka Yazılar, çev. Okan N. Çiftci, İstanbul: Metis Yayınları.

Baudrillard, Jean (2014), Simülakrlar ve Simülasyon, çev. Oğuz Adanır, Ankara: Doğu Batı Yayınları.

Frankl, Victor E. (2007), Duyulmayan Anlam Çığlı̆̆l, Psikoterapi ve Hümanizm, çev. Selçuk Budak, İstanbul: Öteki Yayınları.

Horkheimer, Max (2013), Akıl Tutulması, çev. Orhan Koçak, İstanbul: Metis Yayınları.

Man, Paul de (2008), Okuma Alegorileri, Rousseau Nietzsche Rilke ve Proust'ta Figürel Dil, çev. Mustafa Zeki Çıraklı, İstanbul: Paradigma Yayınları.

Şahin, İbrahim (2012), Haz ve Günah: Bir Tanpınar Yorumu. İstanbul: Kapı Yayınları.

Todorov, Tzvetan (2012), Fantastik, Edebi Türe Yapısal Bir Yaklaşım, çev. Nedret Öztokat, İstanbul: Metis Yayınları.

Tüzer, İbrahim (2016), “Uzun İhsan Efendi’nin Puslu Kitası”, Arka Kapak, 9, s. 24-25. 